\title{
ABOUT NON-POSITIVIST PERSPECTIVE ON LEGAL VALUES IN INTERNATIONAL LAW / Mario Krešić
}

\author{
Mario Krešić \\ University of Zagreb, Faculty of Law, \\ Trg Republike Hrvatske 3, \\ Zagreb; Croatia. \\ mario.kresic@pravo.hr. \\ ORCID: 0000-0002-0014-4157

\section{The paper was originally presented at "The XIVth CEENJ Conference: Jurisprudence in Central and Eastern Europe, Bratislava, 12-13 September} \\ $2019^{\prime \prime}$
}

Submitted: 18 May 2020

Accepted : 07 August 2020

Published : 31 December 2020

\begin{abstract}
The distinction between legal and non-legal values can be made from the aspect of legal system analysis. Since the content of the legal system depends on the identification of norms that establish such content, the problem of the identification is crucial for any kind of consideration of legal values. In discourse of international legal scholars, we can recognize attempts to identify values which are not dependent on the existing social practice. The purpose of this paper is to analyse such an approach to legal values as opposite to the positivistic account of the law and to analyse the main objection to this non-positivist perspective.
\end{abstract}

Key words: theory of law; international law; legal values; peace; rule of law; constitution

Suggested citation:

Kresić, M. (2020). About Non-positivist Perspective on Legal Values in International Law. Bratislava Law Review, 4(2), 31-48. https://doi.org/10.46282/blr.2020.4.2.182

\section{INTRODUCTION}

The important conceptual problem for the international law is the determination of the axiological content of the legal system. The attempt to bring some light to this theoretical problem in this research is inspired by the practical considerations. The discourse of international actors often includes values, although it is not always clear whether these refer to the legal values or other sorts of values the implementation of which cannot be demanded by calling for legal consequences. For example, the argumentation for international intervention can, in the event of a massive human rights violation, be perceived as a form of a political discourse, if we demand intervention be taken to stop such an unjust event and political responsibility assumed. On the other hand, the argumentation could be understood as a legal discourse if it is, for example, based on legal values.

In this contribution the basic conceptual problem is divided in two parts. The first is the problem of the classification of different theoretical approaches to legal values and the second is the applicability of these theories to the international law. The analysis of these problems will be focused on two groups of non-positivist theories and, within the scope of this research, they will be addressed in the following manner: a) by applying the analytical tools as defined in this research to those discourses of legal scholars on legal values which are intuitively considered to be of a non-positivist kind and; b) by exposing this non - positivist approach to criticism based on the concepts known in the legal theory. The purpose of this research is to provide a meta-theoretical framework for the clarification of non-positivist perspective to legal values and to indicate the main challenge(s) to this perspective. We claim that some of these theories can be better 
understood if looked through the lenses of the analytical tools of legal system, fundamental norms, the inherent values of law and the specific qualities of constitutional norms (first thesis); and that the main challenge for their applicability in the international law comes from the specific classification of different types of communities (second thesis).

The outline of the arguments is the following. The theory of the legal system enables us to define the international legal values by the membership of norms - which contain these values - in the legal system (section 2), but this approach raises a new question of the criteria for membership. The concept of inherent values and constitutional values (section 2) enables us to recognize attempts to respond to this question by elaborating legal values independently of the will of states in the theory of international law, either through the determination of international law's inherent values (sections 3 and 4) or by determination of the international constitution whose content does not depend on the actual practice of states (section 5). Among the objections to these theories (section 6), we will elaborate on the one that seems to be the most challenging. It is based on the thesis that the appropriateness of a methodology for the determination of legal values depends on the type of the community in which the methodology aspires to be applied.

\section{LEGAL VALUES IN THE LEGAL SYSTEM}

The distinction between legal and non-legal values can be made from the aspect of legal system analysis. We can commence from the assumptions that the concept of the legal system is applicable to international law, that demarcation between legal and non-legal norms in international law is best explained through the concept of law-applying bodies, and finally, that, at determination of its limits, the international legal system is to be considered in the legal as well as in the socio-political and self-understanding criteria perspectives (for these characteristics of the legal system analysis see Dickson, 2012).

\subsection{Legal and Non-Legal Values}

From the perspective of the legal system, the legal values are values contained in explicit or implicit norms enjoying specific characteristics. Those norms, which we call fundamental norms, can be defined as norms which: a) have specific structure; b) are fundamental; and c) define which legal values belong to the legal system. This stipulative definition of fundamental norms is partially based on the existing insights of legal theorists (e.g. Harašić, 2015; MacCormick \& Summers, 2016, pp. 522-525; Padjen, 2006, p. 119; Visković, 1973, p. 198). ${ }^{1}$

\footnotetext{
1 What we call fundamental norms is close to what some authors name as "value principles". Žaklina Harašić is proposing to use this term since there is no (clear) border between principles and values. The role of general principles is to provide fundamental values according to which all other legal norms shall be interpreted. According to Nikola Visković the existence of value depends on the existence of the value-principle which defines what is desirable and serves as the measure of the proper behavior. Ivan Padjen has emphasized that principles (and this would consequently include what other authors have named as value-principles) are a kind of norms. When the structural distinction between principle and value as well as that between value and goal (value can exist as a measure of action and as an attained goal) is not important, Padjen is using these concepts interchangeably or together, connected by slash. Neil MacCormick and Robert Summers have stressed the importance of values for interpretation. These values may be considered by an interpreter as objectively belonging to the legal order (in terms of natural law or conventionalist legal positivism) and used to justify "decisions which impute to the legislature the intention to uphold fundamental values because of their fundamental character." The references to the structural difference between values, rules and principles will be exposed in the following note.
} 
Firstly, there is a structural difference between values, rules and principles (MacCormick, 2007, p. 29; Padjen, 2006, p. 119). ${ }^{2}$ The fundamental norm containing legal value $X$ can be presented as having the following structure: "the value $X$ ought to be protected" If the value cannot be presented as contained in such a norm but appears in the rules with more precise content as the object of that norm, than it could be more suitable to talk about such values as of a kind of legal objects of norms than as of the legal values enjoying fundamental character. Although there is obvious similarity between fundamental norms containing legal values and other principles regarding the pervasive character of both, the structure of principles will be different as long as they are clustered around the fundamental norms with the aim to help secure the value in the fundamental norm (MacCormick, 2007, p. 29). Secondly, the norm formulated in the abstract way as "the value X ought to be protected" can be perceived as fundamental for two reasons. On the one hand, it is not grounded in other norms with more determined content although some of these norms can be perceived as grounded in other fundamental norms of the same structure. On the other hand, it serves as the ground for other norms of a part or the whole legal system (Guastini, 2011, p. 74). ${ }^{3}$

In this second sense, they are perceived as connected to the identity of a part or the whole legal system, they require from legal bodies to consider legal values in any possible case, and require that all other norms should comply with the values defined by these norms. Thirdly, fundamental norms define which legal values belong to the legal system and in that sense serve as the source of information important, in the first line, for the law-applying bodies. It is generally accepted that law-applying bodies ought to seek solutions for legal problems based on the content of the legal system which, as we propose, also includes fundamental norms containing legal values. From this cognitive aspect of looking on the fundamental norms, especially when having in mind the question of the identity of the legal system, the values contained in these norms can be listed, systematized and presented as a separate part of the legal system which can be called the axiological content of the legal system. ${ }^{4}$

In the context of the legal system analysis, non-legal values can be seen as the content of other kinds of normative systems such as the moral, political, esthetic or

\footnotetext{
2 Padjen stressed the following structural differences between values, rules and principles. The structure of a value: "Q is good" (where Q stands for a state of affairs), of a rule: "If $P$, there ought to be Qe" (where $P$ designates and actor and fact-conditions, if any, while Qe stands for the effect of an action), of a principle: "If $\mathrm{Pi}$, there ought to be Qc" (where Pi designates an actor and a condition that are less determined than conditions of a rule, while Qc stands for the consequence of an action). MacCormick has formulated the concept of value in the following way. "Since it is good to be fair, good to be wise, good to be efficient, good to be reasonable, we can recognize these concepts as naming 'values' [...] Around each we are able to cluster some normative generalizations whose observance helps to secure the value in question. [...] Since they are, like the values in question, pervasive, we do not normally find it helpful to structure them in accordance with the formula 'Whenever OF, then NC'. These are norms that bear on decision-making in almost any circumstance, so there is no point in singling out particular circumstances of application. They are what we commonly call 'principles', or indeed 'general principles'." Since we consider that legal values have to be normative in the legal system, we propose the structure of the fundamental norm containing legal values: "the value X ought to be protected".

${ }^{3}$ According to Guastini any set of norms presupposes some values and principles are those norms which contain such values. The only difference to this view is that we propose concept of fundamental norm (or principle) which firstly posit legal values and these values are then elaborated by (other) principles clustered around legal values. The exposition on fundamental nature of norms positing legal values is following Guastini' s exposition on fundamental character of principles.

${ }^{4}$ The example of the explicit fundamental principle on values is the second article of the Treaty on the European Union: "The Union is founded on the values of respect for human dignity, freedom, democracy, equality, the rule of law and respect for human rights, including the rights of persons belonging to minorities. These values are common to the Member States in a society in which pluralism, non-discrimination, tolerance, justice, solidarity and equality between women and men prevail." (Consolidated versions of the Treaty on European Union and the Treaty on the Functioning of the European Union 2012/C 326/01)
} 
economic system. Such values always remain outside the axiological content of the legal system, as we have described it above. Saying that, it does not mean that they cannot become legally relevant values. But they can become legally relevant only, if the legal system makes values belonging to one of the other systems applicable for resolving legal problems. Law-applying organs are not obliged to consider norms, if explicitly not directed by a legal norm to make decisions based on them (Raz, 1972, p. 844). ${ }^{5}$ There is a difference of what can be required from courts and what can be required from legislation (Dworkin, 2011, p. 405). ${ }^{6}$

\subsection{Identification of Legal Values in International Law}

Since the axiological content of the legal system depends on the identification of the fundamental norms on the protection of values that establish that content, from the perspective of the law as a legal system, the problem of the identification is crucial for any kind of consideration on legal values. We propose to differentiate two approaches to the identification of legal values: positivist and non-positivist.

(1) According to the positivist approach, the legal values in the legal system can be identified in two ways: a) indirect bottom-up model and b) direct up-bottom model (Raz, 1972, p. 844). The indirect bottom-up model of identification of the legal values starts with the reference to the number of particular explicit norms formulated in rules and principles which contains the same value as their object. After that, based on these particular norms of the positive legal system containing the same value, the interpreter identifies the implicit norm on protection of that value as the fundamental norm for a part of or the whole legal system. It remains up to the existing practice of the law-applying bodies whether the fundamental norm can be identified in this way. If this is not the case the identification of the value in existing particular norms serves only as reference to the object protected in those many different norms. This reference is not a legal norm and cannot be used to regulate situations not governed by those rules and principles.

The second positivist way is direct up-bottom model. It consists of direct identification of the fundamental norms of the protection of values for a part of or the whole legal system. These fundamental norms can be explicitly posited in the normative provisions or established through customs. They can also be implicitly contained in the legal system, if the reasoning of their existence is based on other explicit norms or even on doctrinal assumptions on functioning of the particular legal system. This second possibility depends on the practice of the law-applying bodies to develop implicit norms in such a way. Once fundamental norms are identified in this way, values contained in these norms ought to be protected in all cases, even in those not governed by particular rules or principles (Raz, 1972, p. 844).

Following descriptions of these two models, the most plausible way to start with the determination of the axiological content of the legal system is to identify the fundamental norms of the protection of values by researching normative documents or customs. For example, in the international law the most common sources of norms are (traditional) custom and treaties of international law. As mentioned above, the possibility of developing implicit norms depends on the existing practice of law-applying bodies. This method can be considered positivist method as it relies on the existing social practice (which has posited explicit fundamental norms, enabled doctrinal assumptions

\footnotetext{
${ }^{5}$ According to Raz, courts apply the rules of the legal system, but it is also possible to apply the rules of other systems.

${ }^{6}$ This differentiation of values is based on Dworkin's distinction of political and legal rights. The first relates to what citizens may require from legislation, and the second to what they can demand from the court itself.
} 
or established relevant customs) and depends on the existing social practice (of the lawapplying bodies to practice such method).

(2) Non-positivist approach tries to respond to the problem that positivist approach cannot address. The problem is the situation when the existing social practice of the legal bodies seems insufficient for the interpreter to define the axiological content which he/she prefers. This preference can be based on the insight into values which can be identified in the normative systems commonly considered to be law, or in the legal systems of some legal communities. This is, for example, the situation of the deficit of posited fundamental norms in the international law when compared with the municipal law or, at least, some specific municipal legal systems.

In response to the identification problem, we can recognize attempts in the discourse of legal theory to avoid the method of identification of fundamental norms in the existing social practice of the legal bodies, when determining the axiological content of the legal system. In that sense, these methods can be considered as the non-positivist perspective on the legal values. The common characteristic of the non-positivist approaches to the axiological content is that the omission of or a wrong application of the legal values identified by these methods can be interpreted as a "legal error", whereby the bodies are expected to correct such mistakes.

In this research we will deal with two groups of non-positivist methods. ${ }^{7}$ We named the first one as the group of theories on inherent values, and the second one as the group of theories on constitutional values. Before presenting the selected discourses of legal scholars who, as we believe, belong to one of these two groups, we will briefly make some general remarks on the concepts of the inherent and constitutional values which can represent a useful analytical tool in understanding how these theories work.

\subsection{Inherent Values}

The inherent values of law can be defined as values stipulated by given conception of law. As they are important for the functioning of the law itself, without a necessary reference to other purposes outside the law (e.g. economic, political, moral), they can be called the inherent values of law.

The argumentation on the applicability of the inherent values to legal issues is based on the premise that law has specific characteristics (see Dickson, 2012, pp. 2730; cf. Schauer, 2005, p. 498). ${ }^{8}$ These characteristics are not dependent on the specific political, moral or social circumstances of a particular legal system, but on the relevant general practice of humans "living in a society governed by law". Once these characteristics are described, this description can be used by the interpreter in order to deduce the implicit fundamental norms belonging to the particular legal system by the very fact of the existence of the law itself. The values contained in these norms are interpreted as belonging to the axiological content of some legal systems, even if they are not explicitly expressed in any legal provision and accepted by the existing general practice of the legal bodies in a society governed by the law. The practical consideration on the content of law based on the explanatory descriptions of law is manifested in the

\footnotetext{
7 The third approach which can be found in some theories is to determine those political values of the international community which, under specific conditions, can be claimed to emerge as legal. The justification for such claim is not based on the existence of the legal norm directing legal application of the political value, but on the theoretical thesis of the existence of the specific political responsibility of law-applying organs to apply these as legal under specific conditions, even when the application of these norms has not yet been manifested in the practice of any law-applying organs.

${ }^{8}$ At least some theorists construct concepts of law with the reference to the real experiences of those "living in a society governed by law". Besides those who prefer the concept of law as it actually exists, there are other theorists who construct the concept of law to include features of law to which a society should steer.
} 
discussion on what is called the "general principles of law recognized by civilized nations" including the question whether these principles are to be found in the fundamental character of municipal law or in those that are common to all legal systems (Degan, 1997, p. 99; Shiner, 2005). ${ }^{9}$

The different kind of connections regarding these characteristics can be established in different conceptions of law. ${ }^{10}$ Some of the characteristics can be explained as necessary elements without which, according to someone's conception of law, law does not exist or at least is not distinguishable from other normative systems. Some of the examples of such characteristics of law recognized in the theory of law are the following: the existence of the norms of creation, recognition and adjudication, or, in a different version of the same idea, the existence of the norms of creation and application of other norms; the compulsory characteristic of the system; the existence of norms which require specific standards to be met by the process and the result of creation and the application of norms; the capability of the system to govern behavior. The other characteristics can be seen as the instrumental ones, contributing to the realization of the necessary characteristics of the concept of law. For example, the efficiency of law can be seen as an instrumental characteristic of law in measuring the capability of law to realize its necessary characteristics. Finally, some of the characteristics can be seen as conditioned. They are contained in the conception of law under the assumptions of the permanent or contingent, but lasting nature of subjects submitted to law. Consequently, under the assumption that humans are vulnerable and want to survive, the conception of law contains additional characteristics regarding the content of the legal norms, including the norms related to control of violence.

\subsection{Constitutional Values}

Legal values can relatively easily be determined in the legal system as those contained in the explicit or implicit constitutional norms (constitutional values), under the condition that the constitutional norms are ascribed specific characteristics by the legal bodies. The legal theory and doctrine have described the concept of the constitutional norms with specific characteristics based on the practice of the legal bodies in some municipal legal systems. The interpreter of the sources of some legal systems can use this concept as the premise in his argumentation to provide broader meanings of existing fundamental norms, or to stipulate that some norms are implicitly contained in the system as the fundamental norms.

Some of the specific characteristics of the constitutional norms, which are a prerequisite for argumentation on legal values, can be explained if we imagine the interpreter facing problems coming from an "inadequate" concept of the constitutional norms. The following elaboration is based on Riccardo Guastini's description of the different meanings of the constitution (Guastini, 2011, pp. 153-215).

(1) The first problem arises from the concept of the "constitutional norms" reduced only to political facts, because in that case, the existence of the norms is directly dependent on the practices of the political actors. (2) Even if the concept of "constitutional norms" is seen not as a pure political fact, but as a set of norms, the problem remains, if constitutional norms are understood as the result of the agreement between those who accept this set of norms. If "constitutional norms" are perceived as

\footnotetext{
${ }^{9}$ Vladimir Đuro Degan is advocating the latter approach in which the general principles of law constitute a prerequisite for the existence and operation of a legal order.

10 The term conception of law is used for broader definitions of the different characteristics of law. The concept of law refers to the necessary characteristics. The concept of law may be included in someone's conception of law.
} 
an agreement, they are directly related to the will and compromise of those who enter the agreement. This problem can be resolved by explaining the concept of "constitutional norms" as a set of norms which oblige its subjects, not because of the constantly confirmed consent of all subjects, but because of their membership in the community. (3) However, even that is not enough to separate "constitutional norms" from the existing social practices of its subjects, if the concept does not provide a hierarchical superiority of "constitutional norms" over other legal norms. (4) Although not a necessary element for claiming such superiority, the absence or malfunctioning of constitutional supervision as the specific social practice aimed at guaranteeing "constitutional norms", still takes us back to the dependence of the norm-values on the existing social practices. (5) Finally, when all these problems are resolved by the appropriate concept, we can still be confronted with the problem of the modest number of "constitutional norms", if the concept is reduced to the normative document or to constitutional custom that contain only 'constitutional norms' of regulation of the law-operative functions.

\section{INHERENT VALUE OF INTERNATIONAL PEACE}

Hersch Lauterpacht and Hans Kelsen have both elaborated on the connection between peace and international law. In this article, we will only briefly explain why we believe that they assume the value of peace as an inherent value of the law (see Krešić, 2019, pp. 485-501).

Lauterpacht refers to the value of peace in the context of his methodology of law, according to which there is no conceptual difference between the municipal and international law $(1978$, p. 9). The conflict of the rules of international law with the standards of (municipal) law presents the conflict with "the general principles of law and the conception of law itself as generally recognized." (H. Lauterpacht, 2000, p. 431). The practical consequence of his concept of law can be seen in his argumentation intended to be used by international lawyers, with the aim to make the international courts change the existing rule on compulsory adjudication (2000, p. 435). The argument includes the value of peace as "pre-eminently a legal postulate" (2000, p. 438).

Hans Kelsen establishes that connection through his concept of law as coercive order of behaviour. The main change in his approach to the value of peace appears in 1960 when he abandons the value of peace as the necessary element of the concept of law. It can be argued that this conceptual change refers to the stronger peace-keeping function of securing peace through the prohibition of interference into the private sphere of its subjects, while the weaker peace-keeping function of the law remains, in his concept of law, as the coercive order. The practical consequences of his concept of coerciveness can be seen in Kelsen's critique of the UN Charter. Kelsen considers the general international law, before the Charter, as containing the rule of war and reprisals as sanctions against delict. Consequently, the peace-keeping function of the primitive international law provides that any breach of the law for which war was used as sanction could be considered an international delict. The Charter's peace-keeping regime allows sanction to be taken by the UN only for the delict of threat or the use of force by states. Consequently, the Charter "has the undesirable effect of depriving of their legal character all obligations established by general international law which are not at the same time obligations under the Charter" (Kelsen, 1952, p. 58).

This problem of decreased content of the law caused by reduced concept of peace is recognized by contemporary international scholars. The solution can be found in the interpretation of the Charter in two ways: a) to interpret the Charter in such a way as to merge the value of peace and the law and b) to interpret the Charter in such a way as to broaden the scope of actions which require a reaction of the Security Council. The 
first kind of interpretation can be found in the attempt of Alexander Orakhelashvili to interpret the meaning of the value of peace as based on the respect towards the fundamental principles of international law and towards international law considered as a condition of peace.

"This requires viewing peace against the structural background of international law: there will be peace when states can exercise their rights unharassed. Action for peace cannot be validly motivated by contempt for the legal rights of states. If the fundamental rights of a state are essential to peace, then their exercise cannot as such be understood as a threat to or breach of the peace; therefore, from the outset early doctrinal views on the primacy of peace over justice have been articulated inconsistently and constituted a fallacy." (Orakhelashvili, 2011, p. 19; see also Orakhelashvili, 2008, pp. 181-194). ${ }^{11}$

The second kind of interpretation can be observed in Jochen Rauber's view that, based on the wording of the Resolution 794 on Somalia, the meaning of the value of peace could be broadened to include the request for "absence of human suffering from the use of force in inter - and - intra state relations - contrary to the strict wording of the Charter." (2009, p. 59). ${ }^{12}$ If this position would be adopted by the law-applying bodies, the meaning of the value of international peace would be further expanded so that human rights violations represented a violation of the value of peace.

\section{INHERENT VALUE OF THE INTERNATIONAL RULE OF LAW}

In the theory of law, it is common to think of the rule of law value, or at least some of its parts, as an inherent value of the law, although theories differ in terms of whether they refer to its inherency as a necessity or as an instrumental kind.

\subsection{Definition of the International Rule of Law}

The value of the "international rule of law" can be understood as a requirement for subjecting decision-making procedures to the general standards of the international community. In the same way as with its two meanings in the national legal systems (Raz, 1979, p. 212), ${ }^{13}$ this requirement in international law can be understood as a limitation of arbitrary behavior. The ultimate purpose of these limitations is to enable subjects to behave in accordance with international law. For the law to be capable of guiding, it is necessary that, on the one hand, the general standards have a certain quality and that, on the other hand, they ensure a consistent and non-arbitrary implementation of such standards. These two sides of the same requirement set the two subgroups of values of

\footnotetext{
${ }^{11}$ Orakhelahvili expressed the view on the broader meaning of the value of peace in Orakhelahvili (2008): "There is thus no established meaning of peace and security, although there is consensus that this concept relates to more than just absence of war". The author refers to the value of "peace and security" as a "non-law" and seems to define this concept as something opposite to a clear norm which can produce a direct impact on the rights and obligations of states.

${ }^{12}$ Rauber pointed out that there is an ongoing debate on which philosophical ground of this interpretation can be based. For our purposes, it is enough to show how the value of peace can be determined as a legal value based on the conception of law as application of the international legal norms, i.e. securing the peace through law, whereby the meaning of this value can vary from the minimal to the maximum covering of the interference in the private sphere of its subjects. The justification of interpretation of the value of peace represents a separate issue.

${ }^{13}$ Raz makes distinctions between the broader and the narrower meaning of the notion of the rule of law. "Taken in its broadest sense this means that people should obey the law and be ruled by it." This meaning, as Raz says, has been taken over from Jennings and his work The Law and the Constitution (London, 1933). "But in political and legal theory it has come to be read in a narrower sense, that the government shall be ruled by the law and subject to it."
} 
the international rule of law (Raz, 1979, pp. 214-218; 2019, pp. 3, 8-9), ${ }^{14}$ that the axiological part of international law contains, if the rule of law is an inherent value of law.

The first group includes values of legality, legal certainty and legal equality that must first and foremost be met by general international standards. The second group includes values referring to the compliance of conduct with the general standards. The legal value of compulsory international adjudication allows states to protect their rights in the event of violation of the general international standards, and it guarantees the values of legal certainty, legal equality and legality.

If we accept that the inherent value of the rule of law includes the value of compulsory international adjudication and that in the international community it does not exist, there emerges an issue of explaining the existing international community as functioning based on the rule of law.

\subsection{Theory of Compulsory International Adjudication}

The current attitude of the international community towards the legal value of international adjudication is reflected in the omnis judex rule of international law, according to which everyone is the judge in its own cause. Both authors, Lauterpacht and Kelsen, have noticed that the rule is confirmed in the advisory opinion in the Eastern Carelia Case and both have provided a general argumentation in favour of compulsory adjudication. For the purpose of this research, it is sufficient to focus on their point that this rule is in conflict with the inherent values of peace, legal certainty and equality. For Lauterpacht, this conflict is seen as the incompatibility with "the general principles of law and the conception of law itself as generally recognized." (2000, p. 431). He looks at the value of compulsory adjudication from the aspect of efficiency of law, but also from the aspect of its unreplaceable function to preserve some other essential values of law. The omnis judex principle confirmed in the above mentioned court opinion has to be, as a matter of law, inquired into and possibly corrected by the new decisions of the courts (Lauterpacht, 2000, p. 435). ${ }^{15}$ For Kelsen, the conflict is perceived as the inconsistency with the other principles of general international law and the conception of law with his evolution thesis. He considers the value of compulsory adjudication as instrumental and as contributing to the efficiency of securing other legal values, and also proposes de lege lata solutions to replace the omnis judex principle.

\footnotetext{
${ }^{14}$ In his 1979 elaboration on the rule of law, Raz emphasized eight principles which can be grouped in two groups as mentioned here. In his 2019 account on the rule of law principles, he explicitly mentions principles of generality, publicity, non-retroactivity, and stability which are the same as in the previous work. Among other principles mentioned in the later work, some of them (fair and unbiased process of making decisions, opportunities to consider arguments) can be connected with those mentioned in his previous work regarding application of law while few of them represent an addition to the previous considerations (decisions should be related to declared reasons, it should be made by observing the interest of the governed and by acting in the interest of governed, the doctrine of the rule of law should be part of public culture embedded in education and public discourse; Ibid.). Although the application of law by courts is not specifically mentioned as before, from the text it is obvious that Raz is still considering the principles regarding the compliance of law, among others, by courts as belonging to the rule of law. For example, when commenting Lord Bingham's list of the rule of law principles, Raz says that this list is considerably overlapping with his own with only two omissions in Raz list: protection of human rights and compliance by the state with its obligations in international law. Lord Bingham's list includes the following principles: laws should apply equally to all, a way of resolving disputes which the parties cannot themselves resolve should be established, the adjudicative procedures should be fair.

15 "The international lawyer must not regard himself as being prevented from attempting that task on the ground that the Permanent Court of International Justice has repeatedly expressed the opinion that it is a clear rule of international law that a State cannot be compelled against its will to submit its disputes with other States for international adjudication, and that its jurisdiction is strictly limited by the will of States."
} 
Both authors consider the realization of the value of peace as connected with the realization of the value of compulsory adjudication. Kelsen believes that "nothing is more dangerous for peace than the unresolved dispute and peaceful settlement of disputes for which no binding action has been provided." (2008, p. 32). Lauterpacht points out that "the reign of law, represented by the incorporation of obligatory arbitration as a rule of positive international law, is not the only means for securing and preserving peace among nations. Nevertheless, it is an essential condition of peace." (2000, p. 437). In the third section, we have seen that both authors consider peace not only as a mere absence of violence. Peace through application of law belongs to their conception of law and compulsory adjudication contributes to the application of law.

According to Lauterpacht, the value of legal certainty is of the essence to law. It is the certainty of the final decision in a dispute by a body other than the parties to the dispute, which cannot be achieved by parties themselves. "The object of law to secure order must be defeated if a controversial rule of conduct may remain permanently a matter of a dispute. It must remain so as long as no agencies exist capable of determining existing legal rights with finality and without appeal." (2000, p. 425). Kelsen considers that the establishment of compulsory adjudication in international law "is a means, perhaps the most effective means to maintain a positive international law." (2008, p. 45). Obviously, if the law is not maintained efficiently, there arises uncertainty as to how the states should behave.

Finally, the value of equality of states loses its true meaning without international adjudication. For Kelsen, equality is both a "tautological expression of the principle of legality i.e. the principle that the general rules of law ought to be applied in all cases in which according to their contents, they ought to be applied" (2008, p. 37) and the equality of the capacity of duties subjected only to international law (2008, pp. 35-36). When he argues that compulsory adjudication is not in contradiction with the legal value of equality, he in fact provides arguments as to why compulsory adjudication can contribute to that value. More meritoriously, he emphasizes that the submission to law guarantees the coexistence of states as equal, while lack of its application leads to anarchy (2008, pp. $31,49)$. According to Lauterpacht, "there is indeed a glaring contradiction in the idea that, in a society of states which are ex hypothesi independent of one another, and in relation of equality to each other, one state may legally claim the right to remain the judge in a dispute in which the rights of another state are involved." (2000, p. 429). In his view, "any doctrine which, in relations between States, postulates the individual interest of the single State as the ultimate standard of values and of legal obligation amounts to a negation of international law." (2000, p. 430).

\subsection{Theory of Interactional International Law}

Unlike the previously described way of justifying the value of the international rule of law, the theory of Juta Brunée and Stephen Toope on the interactional model of international law (2010) is adapted to the existing institutional gaps in the international community. The theory includes the two values described on the basis of Fuller's general theory of law. The first one is the inherent value of reciprocity, the second one being the inherent value of the rule of law which corresponds to the description provided in the previous section 4.1 .

The value of reciprocity can be understood in several ways. Brunée and Toope refuse to attribute to this value the meaning in terms of mere reciprocity between states as a deduction of directly achievable interests, or as a systemic reciprocity according to which states cooperate to uphold a rule of international law only when they anticipate a long-term interaction on the issue, whereby the benefits of defection do not significantly 
outweigh those of cooperation. Opposite to such views, Brunée and Toope share Fuller's idea of the value of reciprocity that has a deeper meaning as the fidelity to interaction through fulfilment of duties (2010, p. 38).

Why should international law be in conformity with the values of the rule of law? Since international law is not based on the hierarchy of norms, the criterion of formal validity cannot establish the legal obligation of states. In the international context, this is only possible when a norm a) is legitimate in the eyes of addressees and b) supports the value of reciprocity. A norm is legitimate when it corresponds to the first group of values of the rule of law. The second group of values of the rule of law regarding compliance, support the value of reciprocity. Even though the emergence of the centralized legal agencies is not perceived as a necessary condition, due to the presupposed existence of the value of "reciprocity as fidelity", Brunée and Toope realize that the law must be applied in order to maintain such a value. "When explicit rules are unrelated to how states and other international actors actually behave, fidelity is destroyed." (2010, p. 35). Fuller's eighth value of the rule of law, that of congruence between law and official action, is overtaken by the authors in their own model of international law in a specific way. They interpret this value as a requirement of "congruence amongst the actions of a majority of international actors." (2010, p. 35). We can conclude that the interactional conception of international law cannot exist without the value of reciprocity as fidelity, and that that value cannot exist without accepting the content of the legal value of the rule of law. The acceptance should include both value groups of the rule of law value: a) the legal values that the general norms have to meet and $b$ ) the legal value of compliance conceived as the principle of majority.

Brunée and Toope have found their theory to have practical consequences for the existing norms of international law. After analysing the norm on the prohibition of torture in light of the eight "rule of law" standards, they found a problem with the criteria of clarity and congruence and, although they were "not comfortable with the conclusion", that the norm does not meet the rule of law standards. Even more, they stressed the possibility that "the formal existence of an absolute prohibition on torture could still become a dead letter." (2010, pp. 251, 268, 269-270). It might be argued that their analysis was purely descriptive and intended to emphasize the problems of international law. However, if their theory on international rule of law is consistent, the international judges might come to the same conclusions.

\section{CONSTITUTIONAL VALUES OF INTERNATIONAL LAW}

The theories of the constitutionalization of the international order enable us to find legal values in the constitution of the international community. The problem is how to prove the existence of such kind of constitution that would enable an extensive interpretation in determining legal values? The solution to the problem can be in ascribing the desirable characteristics to the constitutional norms and, subsequently, in ascribing the status of constitutional norm to those international norms for which the interpreter claims to be in line with desirable characteristics. There are two main theoretical approaches to determination of the relevant characteristics. The first one looks for the relevant forms of practices which allegedly produce constitutional norms as opposite to ordinary international norms. The second approach determines the important material content of norms which makes such norms qualified to be ascribed with the status of 
constitutional norms. ${ }^{16}$ We can distinguish two versions of the second approach depending on whether the material content is the matter of theoretical thesis on what counts as the material content of any constitution, or it is the matter of interpretation of political responsibility within a specific international community (the second version is out of the scope of this research). ${ }^{17}$ Some scholars on constitutional international norms seems to combine the first approach to constitutional norms with the second version of the second approach (Kirchner, 2004, pp. 59-61). ${ }^{18}$

These different approaches can result in the different lists of constitutional international norms. The difference in determination of the constitutional international norms can also appear due to the different background context of the legal practice from which the interpreter is assessing whether or not an international norm has the relevant characteristics for the assignment of the constitutional status to that norm. The interpreter can search for the constitutional norms from the context of international order, particular regime (e. g. EU) and national order. ${ }^{19}$

We will make observations on some of the desirable characteristics of constitutional norms which can be derived from the theory of Bardo Fassbender, one of the leading advocates of the international law constitutionalization (Fassbender, 2009). We will briefly present his theory through five main features which can be compared with the model of constitutionalization as shown in section 2.3.

(1) According to Fassbender, the international constitution is not a political fact but a set of norms. He believes that there already exists a constitutional law of the

\footnotetext{
${ }^{16}$ Some concepts such as general principles of law, ius cogens and erga omnes norms can be used by both approaches for discovering constitutional norms. These concepts can be used either by ascribing to the norm the status of ius cogens, erga omnes norms or general principles and, consequently, the constitutional status based on findings of the relevant "constitutional" practices (recognized for instance in the specific producing of legal texts or specific customs); or by determination of the important material content of norms (found in the legal system or in non-legal systems) which makes these norms qualified to be ascribed with the status of ius cogens norms, erga omnes norms or general principles and, consequently, with the status of constitutional norms.

17 If the second approach to constitutional norms is based on the concept of the political responsibility, we consider it as belonging to the specific non-positivist approach to legal values (see note 7) which will be presented and analyzed in the separate research.

${ }_{18}$ For instance, according to Stefan Kirchner obligation can be considered as having constitutional status if it arises from the UN Charter, general principles of law, ius cogens rules and erga omnes rules. After that, the author distinguishes those constitutional rules determined by the rules of the international law itself (lex lata) and those rules depending on values which are important enough to be considered as protected by constitutional rules. In addition, the international community as a whole is constitution-making power and this power is not only limited to the community states but includes non-state actors (international organizations, NGOs, networks) which are involved in decision - making, often in informal ways and which impact the material content of international law.

19 If it is accepted that different contexts can provide different results, the first question is which context is the relevant one, and the second question is how to keep the consistency of all three kinds of legal orders (if this consistency is valued as something to be achieved) when interpretation results either in different interpretation of the constitutional international norms, or in the interpretation of different constitutional norms of international order and different constitutional norms of particular regime and/or national order. In the research of Cadi case by Juliane Kokott and Christoph Sobotta we can found how both questions in regard to the rights of the individuals can appear in practice. Firstly, the court of the regional regime has decided (Court of First Instance of the European Communities, Kadi v. Council and Commission, Case T-315/01, Judgement (21 September 2005)) the case based on its interpretation of the constitutional international norms. Lately, the court of the same regime has decided the case (Court of Justice of the European Communities (Grand Chamber), Kadi and Al Barakaat International Foundation v. Council and Commission, Joined Cases C-402/05 P and C-415/05 P, Judgment (3 September 2008)) based on the interpretation of constitutional norms of that regime. The authors provide a theoretical explanation, derived from doctrinal practice of national courts, how this, insisting on constitutional norms of the regime in the second judgement, can be concealed with the need to keep the consistency of international law and the law of that regime (Kokott \& Sobotta, 2012).
} 
international community established by the UN Charter and by core conventions around it. The problem of international practice deviating from the international constitution is solved by Fassbender's conceptual difference between the actual and the normative constitution. ${ }^{20}$ The Charter, as a normative constitution, should guide and control the actual relationships of power, rather than describe or reflect them.

(2) Unlike the League of Nations' Covenant which resembles more a multilateral treaty, the UN Charter represents the constitution of an international political community within which international law operates. It is obligatory regardless of the will of states to reach an agreement, because it is based on their membership in the community. The Charter also constrains non-member states, because it is both the constitution of the UN organization, in that context procedural norms only bind UN member-states, and because it represents the constitution of the international community as a whole and, therefore, its substantive norms bind all states (Fassbender, 2009, p. 116). The constitution of the international legal community embraces international law in its entirety, and international general law cannot exist as independent of the Charter.

(3) The hierarchical superiority of the international constitution is an important feature for its separation from the will of states. According to Fassbender, it is "the highest layer in a hierarchy of norms of international law." (2009, p. 118).

(4) The shortcoming of international law is that it lacks sufficient judicial review in protection of its norms. According to Fassbender, the discrepancy between constitutional norms and practices, that is, the inefficiency of the normative constitution, is the result of the lack in judicial practice, because the function of the courts is to determine violation of the constitution and to reestablish the constitutional order (2009, pp. 100, 110). ${ }^{21}$ Due to lacking international adjudication, Fassbender turns his focus on states. They represent an important agency for preservation of the core of the constitution of the international community.

(5) The problem of the insufficient number of constitutional values in the Charter is facilitated by regarding the constitution not as a single written legal act, but as a substantive constitution regulating a specific type of matter that belongs to the branch of constitutional law. As mentioned before, Fassbender believes that constitutional law includes not only the UN Charter, but also the core conventions around it, such as conventions on international human rights, for example, the international human rights covenants or the Convention on the Prevention and Punishment of Genocide. "[T]hese treaty and customary rules can be ascribed constitutional quality if, and to the extent that, they characterize in detail, or further develop, the constitutional law of the Charter." (2009, p. 122).

The proposed theoretical model grants us a valuable source of international legal values. Provided this theory is accepted, the legal science on international constitutional law as a subdiscipline of public international law (Fassbender, 2009, p. 1) can determine the legal values of the international order. The theory can have direct practical

\footnotetext{
${ }^{20}$ Fassbender also points to a different view of the real and the normative constitution of Karl Loewenstein (Loewensten, 1957, pp. 148-149). "[T]o be real and effective, it [a constitution] must be faithfully observed by all concerned; it must have integrated itself into the state society. If this is the case, a constitution may be spoken of as normative: its norms govern the political process, or the power process adjusts itself to the norms." (Loewensten, 1957, p. 148). Loewenstein calls the "nominal constitution" the situation when: "The factual state of affairs does not, or not yet [or, we may add, not anymore] permit the complete integration of the constitutional norms into the dynamics of political life." (1957, p. 149).

${ }^{21}$ Although the judicial function of the UN is undeveloped, especially because of a lack of compulsory jurisdiction of the Court of Justice, Fassbender emphasizes the importance of the quasi-judicial function of the Security Council. "Finally, it should be mentioned that the Security Council, in spite of its prevailing political character, also performs a semi-judicial function, in particular when recommending, under Chapter VI of the Charter, terms of settlement of international disputes or situations which might lead to international friction."
} 
consequences, for example, when assessing the Security Council's reform proposal. Fassbender wonders whether the decision on a UN reform belongs to a purely political discourse through which states decide what they want or there exist binding legal standards when states consider different solutions. Since such standards cannot be found in general international law, Fassbender finds them in the Charter in capacity of constitution of states. This theory, according to Fassbender, might be useful for solving theoretical problems and for interpreting the Charter (2009, p. 9).

\section{CRITICS ON THE THEORIES ON INHERENT AND CONSTITUTIONAL VALUES OF INTERNATIONAL LAW}

The critics that challenge the previously mentioned theories of the legal values of international law can be categorized into three groups: a) critics due to conflicts of values, b) critics due to different interpretations of values and c) critics due to the problematic perceptions of the nature of the international community.

The first two groups do not present an unsolvable obstacle. The conflicts of values can be interpreted, as Kelsen and Lauterpacht claim, as an argument to strengthen the thesis on the existence of values of international law: peace and the rule of law. The human rights' values do not have to be a necessary reason for rejecting the value of the international rule of law if an appropriate institutional framework for the protection of human rights is to be established. Also, different interpretations of the inherent and constitutional values of the legal order do not weaken the argument that such values exist. The main challenge for the theories on the existence of inherent and constitutional values comes from the argument that their existence depends on the presupposed features of the legal community.

Although the international law doctrine can use both methodological approaches for the determination of the international legal values - by researching inherent and constitutional values independent from the existing practice, or by determining the values exclusively through researching the practice of the legal bodies - here the question arises which of these two approaches is most suitable for describing international legal values. It seems that suitability of methodology is related to the characteristics of the community we describe. To clarify this suitability thesis, we will use Dworkin's community models.

Ronald Dworkin proposes three models of communities: de facto community, rulebook community and community of principles (1986, p. 208). Community models serve as the ideal types for describing the "attitudes members of a political community would self-consciously take toward one another if they held the view of community the model expresses." (1986, p. 209). Thus, if the states, that is, their officials and citizens, see the international community just as a factual one, they would have a different kind of expectations of and concerns for other states and for the international community, than if they look through the prism of the other two models.

In the first model, the states have no interest in each other and interaction takes place to the extent necessary to satisfy their own interests, so the possible emergence of common rules and values is limited to immediate interests rather than a long-term cooperation for everyone's benefit. In the second model, relations are established through political compromises with the aim of long-term planning of joint state activities. While in the third model, the states establish relations, not only through negotiations and political compromises like in the rulebook model, but also through common values that feel binding regardless of current compromises.

Accordingly, in the third model the existence and the content of legal values is not solely the result of a political compromise of all or majority of states or the most influential states in the community. It does not appear to be problematic to argue that in 
this type of a community, some values inherent to law, such as peace through law or rule of law, exist irrespective of the existing will of its members. Likewise, the argumentation on constitutionalization and international constitutional values, that might include the mentioned inherent values as well as other values important for the community, such as human rights values, can be seen as a contribution to determining the community values which oblige the states and the legal authorities, regardless of their actual practice. What about the correlation between the model of the community and the existence of inherent and constitutional values in the first and the second model?

In the first one, the frail type of community relations, questions the existence of any kind of legal obligation to respect norms, including those containing legal values. If, for example, we say that there is a value of peace in such a community, then it is disputable whether its members feel legally obliged not to cause war, or they avoid war only because they feel it is their will to do so due to political reasons. In the second model, subjects are as selfish as in the first one, but are legally obliged to respect the mutually binding rules, although only those that arise from negotiation and compromise. This general attitude could possibly have one exemption - the pacta sunt servanda principle, in which the legal nature according to some authors cannot be explained by consent of states (Franck, 1988, p. 755). Following Dworkin's description of this model, states consider that the content of the rules exhausts their obligations and that rules contain nothing more than what they explicitly agree on, whereby general rules, such as those in treaties, are created in a way that "each side has tried to give up as little in return for as much as possible" (1986, p. 210). The argumentation on inherent or constitutional values whose existence and content is not explicitly agreed on in a particular rule or recognized in the current practice, cannot be a persuasive justification for the source of legal obligations (1986, p. 210). ${ }^{22}$ Therefore, international agencies authorized for the implementation of law, if they exist at all, would be obliged to make their decisions in the way consistently reflecting the will of the states at application of standards that the states have agreed on. In this context, the order cannot be considered constitutionalized, if this means that we are to separate its norms from the will of states, and an agreement cannot become a constitution. Similarly, the inherent values of law can be disregarded in the international rulebook community as scientific, political or moral concepts but not as legal values to be protected in all cases no matter what legal provisions or practice looks like.

\section{CONCLUSION}

The analytical framework consisting of the following concepts - legal system, fundamental norms, inherent values and constitutional norms - can facilitate a better understanding of the non-positivist approach to legal values. The legal value can be defined through the legal system analysis. Since the legal system consists of norms, it is obvious that legal value has to be related to some norms in the legal system. This norm, named as fundamental norm, has specific structure ("the value X ought to be protected"), it is fundamental (not grounded in other norms with exception of other fundamental norms and it grounds other norms) and serves as the source of information for the cognition of the set of legal values of the system (axiological content). The non-positivist approach is described as having the following characteristics: 1) Those following this

\footnotetext{
22 According to Dworkin, the rulebook community supposes that "members of political community accept a general commitment to obey rules established in a certain way that is special to that community [...] They have no sense that the rules were negotiated out of a common commitment to underlying principles that are themselves a source of future obligation; on the contrary, they take these rules to represent a compromise between antagonistic interests or points of view."
} 
approach try to resolve the problem they think to exist in the international law (some others may not think that this is a problem or that they have to resolve it). The problem is the gap between the existing practice of legal bodies - production of normative documents, customs of states, acts of law-applying bodies - and the axiological content which the interpreter prefers, especially when compared with the axiological content of the municipal law. 2) This gap is considered by the proponents of the non-positivist approach as a legal error which should be corrected by legal bodies. 3) The axiological content of the international law (which reflects the preferences of the interpreter) is determined by using the methods which avoid the existing social practice in the international law. Two of these methods are: a) the identification of the inherent values defined as those stipulated by the given conception of law and b) the identification of the constitutional norms ascribed with the specific characteristics. The summarized presentation of the discourse of selected legal scholars has shown that these characteristics can be recognized in their theories. Each of the theories exposed - theory of the international peace, theory of compulsory adjudication, theory of interactional international law and the theory of international constitutional values - use one of nonpositivist methods (characteristic 3); intends, as it has been shown, to have practical consequences in first line for the interpretation of the existing law (characteristic 2) and can be read as the attempt of their designers to "enrich" the axiological content with those fundamental norms which are, according to the opinion of authors, implicitly contained as such in the international legal system (characteristic 1).

In regard to the three kinds of arguments that can be developed in more detail against the presented theories, we have briefly introduced counterarguments for the two of them (interpretation of the values and conflict of the values). That leaves us with the third objection to non-positivist approach based on the idea of different types of communities: de facto community, rulebook community and community of principles. The methodology of determining legal values as independent of the existing practice is suitable only if there is a certain type of interconnection in the international community that suits the community of the principles' model. We can formulate a suitability thesis in the following way: the suitability of the methodology to be applied for the determination of legal values depends on the community model that provides the best description of the researched community. The vulnerability of the theories on the inherent and constitutional values arises from the impression that the present international community is still more suited for the rulebook model in which the existing practice of international agencies, whose decisions are binding for all states, as well as the practice of the states themselves, influenced by the most powerful ones, are the main, if not the only source for determining the existence and the content of legal values.

Even if the presented theories are not suitable for the determination of legal values in the model to which the existing international community might belong, there is no doubt that they can easily be used for de lege ferenda analysis. ${ }^{23}$ We can read them as positing the scientific, moral or political goals of peace through law, rule of law and human rights whose achievement requires the following: a) the broadened definition of the peace and the Security Council's obligation to make decisions by application of law; b) international adjudication established as compulsory instrument for all international disputes and an institutional mechanism introduced for guaranteeing the compliance of states with the international law and; c) the international constitution - with the appropriate characteristics of its norms and the content which includes the values of

\footnotetext{
${ }^{23}$ As we have seen in the section on constitutional norms, the non-positivist approach can be useful in reforming the existing international law by explicitly formulated more advanced norms.
} 
peace, rule of law and human rights - established as the source of law for the international law-creating and law-applying bodies.

\section{BIBLIOGRAPHY:}

Consolidated versions of the Treaty on European Union and the Treaty on the Functioning of the European Union 2012/C 326/01.

Court of First Instance of the European Communities, Kadi v. Council and Commission, Case T-315/01, Judgement (21 September 2005).

Court of Justice of the European Communities (Grand Chamber), Kadi and Al Barakaat International Foundation v. Council and Commission, Joined Cases C-402/05 P and C-415/05 P, Judgment (3 September 2008).

Brunée, J., \& Toope, S. J. (2010). Legitimacy and Legality in International Law: An Interactional Account. New York: Cambridge University Press.

Degan, V. Đ. (1997). Sources of International Law. Hague: Martinus Nijhoff Publishers.

Dickson, J. (2012). Towards a Theory of European Union Legal Systems. In J. Dickson \& P. Eleftheriadis (Eds.), Philosophical Foundations of European Union Law. (p. 490). Oxford: Oxford University Press.

Dworkin, R. (1986). Law's Empire. Massachusetts: Harvard University Press.

Dworkin, R. (2011). Justice for Hedgehogs. Cambridge: Harvard University Press.

Fassbender, B. (2009). The United Nations Charter as the Constitution of the International Community. Leiden: Koninklijke Brill NV.

Franck, T. M. (1988). Legitimacy in International System. The American Journal of International Law., 82(4), 705-759.

Guastini, R. (2011). La sintassi del diritto, seconda edizione. Torino: Giappichelli.

Harašić, Ž. (2015). More about teleological argumentation in law. Pravni Vjesnik, 31(34), 23-50.

Kelsen, H. (1952). Principles of International Law. New York: Rinehart and Company.

Kelsen, H. (2008). Peace Through Law. New Jersey: The Lawbook Exchange, Ltd.

Kirchner, S. (2004). Relative Normativity and the Constitutional Dimension of International Law: A Place for Values in the International Legal System? German Law Journal., 5(1), 47-64.

Kokott, J., \& Sobotta, C. (2012). The Kadi Case - Constitutional Core Values and International Law - Finding the Balance? European Journal of International Law., 23(4), 1015-1024.

Krešić, M. (2019). The role of peace in Kelsen and Lauterpacht's theories of International Law. Zbornik Radova Pravnog Fakulteta u Splitu., 56(2), 485-501.

Lauterpacht, H. (2000). Functions of Law, The Function of Law in the International Community. New Jersey: The Lawbook Exchange, Ltd.

Lauterpacht, H., \& Lauterpacht, E. (1978). International Law: Volume 1, The General Works: Being the Collected Papers of Hersch Lauterpacht (Elihu Lauterpacht). (E. Lauterpacht,Ed.). London: Cambridge University Press.

Loewensten, K. (1957). Political Power and the Governmental Process. Chichago: University of Chicago Press.

MacCormick, N. (2007). Institutions of Law: An Essay in Legal Theory. Oxford: Oxford University Press.

MacCormick, N., \& Summers, R. (2016). Interpretation and Justification. In N. MacCormick \& R. Summers (Eds.), Interpreting Statutes: a comparative study. (pp. 511-544). London, New York: Routledge.

Orakhelashvili, A. (2008). The Interpretation of Acts and Rules in Public International Law. New York: Oxford University Press. 
Orakhelashvili, A. (2011). Collective Security. New York: Oxford University Press.

Padjen, I. (2006). A Policy oriented search for basic European Values. Dignitas, (71-72), $115-137$.

Rauber, J. (2009). The United Nations - a Kantian Dream Come True? Philosophical Perspectives on the Constitutional Legitimacy of the World Organization. Hanse Law Review., 5(1), 49-76.

Raz, J. (1972). Legal Principles and the Limits of Law. The Yale Law Journal., 81(5), 823-854.

Raz, J. (1979). The authority of law: Essays on Law and Morality. Oxford: Oxford University Press.

Raz, J. (2019). The Law's Own Virtue. Oxford Journal of Legal Studies., 39(1), 1-15.

Schauer, F. (2005). The Social Construction of the Concept of Law: A Reply to Julie Dickson. Oxford Journal of Legal Studies., 25(3), 493-501.

Shiner, R. A. (2005). Volume 3: Legal Institutions and the Sources of Law. In E. Pattaro (Ed.), A Treatise of Legal Philosophy and General Jurisprudence. Dordrecht: Springer.

Visković, N. (1973). Legal Value and the Concept of Law: Contribution to the Theory of Legal Value. Zbornik Radova Pravnog Fakulteta Splitu., 10, 195-224. 